\title{
STRATEGI IBU MENANAMKAN PENDIDIKAN KARAKTER DALAM \\ LINGKUNGAN KELUARGA
}

\author{
Oleh : Syarifah Fauzi'ah
}

Dosen tetap pada fakultas Adab dan Humaniora

UIN Alauddin Makassar

\begin{abstract}
:
This paper aims to understand the mother's strategy in instilling character education in the family environment. Family environment is the first and main educational institution for children to get knowledge especially related to the value of knowledge or character education.

This paper, it is understood that the position of women in the Islamic view is glorious. As proof of her noble position of the mother in Islamic teaching, a mother is entitled to devotion of a child as much as three times more than the father. Glory was also pointed out that heaven lies at the feet of mother even the pleasure of Allah depends on the parents, especially mothers.

Besides, a mother plays crucial role in shaping the character of children. To perform such a noble task, a mother can do things like: giving a child a good name, maximizing children's brain development, training independence in the House, communicating healthy with children and making nature as a school for children.
\end{abstract}

\section{Abstrak:}

Tulisan ini bertujuan untuk memahami strategi ibu menanamkan pendidikan karakter dalam lingkungan keluarga. Lingkungan keluarga merupakan lembaga pendidikan pertama dan utama bagi anak mendapatkan ilmu khususnya terkait dengan pengetahuan nilai atau pendidikan karakter.

Hasil penelitian menunjukkan bahwa Tulisan ini mengungkap bahwa Posisi ibu dalam pandangan Islam sangatlah mulia. Sebagai bukti mulianya kedudukan ibu dalam ajaranIslam, seorang ibu berhak memperoleh bakti dari seorang anak sebanyak tiga kali lipat dibanding ayah. Kemuliaan itu juga disinyalir bahwa surga terletak di telapak kaki ibu bahkan ridha Allah tergantung pada ridhahnya orangtua terutama ibu.

Disamping itu seorang ibu sangat berperan dalam membentuk karakter anak. Untuk melakukan tugas mulia tersebut seorang ibu dapat melakukan berbagai hal seperti: Memberi nama yang baik pada anak, Memaksimalkan perkembangan otak anak, Melatih Kemandirian dari Dalam Rumah, Berkomunikasi Secara Sehat dengan Anak serta Menjadikan Alam sebagai Sekolah bagi Anak.

Kata Kunci: Strategi, ibu, pendidikan karakter, lingkungan, keluarga

\section{A. Latar Belakang}

Secara umum, karakter sering diasosiasikan dengan tempramen yang memberinya sebuah definisi yang menekankan unsur psikososial yang dikaitkan dengan pendidikan dan konteks 
lingkungan. Dari sudut pandang behavioral yang menekankan unsur somatopsikis yang dimiliki individu sejak lahir, karakter dianggap sama dengan kepribadian. Dalam hal ini kepribadian dianggap sebagai ciri atau sifat khas dari diri seseorang yang bersumber dari bentukan-bentukan yang diterima dari lingkungan, termasuk kehidupan di lingkungan keluarga pada masa kecil dan bawaan seseorang sejak lahir. (Koesoema A, 2010: 80).

Berbicara tentang pendidikan karakter, mau tidak mau kita harus mempertanyakan secara kritis gambaran manusia seperti apa yang ada dalam kepala kita. Apa yang dipaparkan oleh Koesoema dengan mengutip kata Freire bahwa praksis pendidikan mengandalkan sebuah konsep manusia dan dunia dan untuk menjawab pertanyaaan-pertanyaan yang muncul dalam pendidikan, kita perlu mengenal struktur antropologis yang ada dalam diri manusia itu sendiri dan setiap usaha untuk memahami pendidikan karakter pertama-tama yang harus dilakukan adalah menjawab pertanyaan fundamental tentang struktur dasar antropologis kodrat sebagai manusia.

Pada dasarnya, secara inderawi kita dapat membedakan orang baik dan orang tidak baik. Pertanyaannya adalah apakah orang-orang yang baik dan tidak baik itu dapat dikatakan orangorang yang memiliki keutamaan dan orang-orang yang tidak memiliki keutamaan. Apakah sifatsifat baik dan keutamaam itu boleh dikatakan keistimewaan bagi orang-orang tertentu saja yang memang dilahirkan dengan bawaan sejak lahir? Jika itu benar, maka pendidikan karakter tentu saja tidak diperlukan lagi. Tidak ada gunanya pendidikan karakter karena pada dasarnya setiap manusia yang baik akan selalu manjadi baik dan sebaliknya, setiap manusia yang tidak baik akan selalu menjadi tidak baik. Pendapat ini tentu saja menimbulkan kontroversi, sebab dalam kenyataannya kita melihat ada saja orang yang sejak dahulu dikenal sebagai orang-orang jahat, tetapi kini menjadi orang baik, dan juga sebaliknya. Dalam proses perubahan itu, menunjukkan bahwa manusia itu memiliki daya dinamis yang bisa berubah, dan jika manusia memiliki daya dinamis itu, maka pendidikan karakter tentu saja merupakan kesempatan yang memberi peluang bagi penyempurnaan diri manusia.

Penguatan pendidikan karakter dalam konteks sekarang sangat relevan untuk mengatasi krisis moral yang sedang terjadi di negara kita.( Darmiyati Zuhdi, 2009, h. 84). Diakui atau tidak saat ini terjadi krisis yang nyata dan menghawatirkan dalam masyarakat dengan melibatkan milik kita yang paling berharga, yaitu anak-anak. Krisis itu antara lain berupa meningkatnya pergaulan 
seks bebas, maraknya angka kekerasan anak-anak dan remaja, kejahatan terhadap teman, pencurian remaja, kebiasaan menyontek, penyalahgunaan obat-obatan, pornografi, perkosaan, perampasan dan perusakan milik orang lain sudah menjadi masalah sosial yang hingga saat ini belum dapat diatasi secara tuntas. Perilaku remaja kita juga diwarnai dengan kebiasaan bullying (kekerasan) dan tawuran di sekolah. Akibat yang ditimbulkan cukup serius dan tidak dapat lagi dianggap sebagai suatu persoalan sederhana karena tindakan ini telah menjurus kepada tindak kriminal. Perilaku orang dewasa juga setali tiga uang, senang dengan konflik dan kekerasan atau tawuran, perilaku korupsi yang merajalela, dan perselingkuhan.

Indonesia dapat menjadi bangsa yang kuat punya peradaban yang unggul dan mulia jika kita memperkuat pendidikan karakter di semua lini kehidupan. Pendidikan sangat urgen untuk diperhatikan karena orang berilmu dijamin oleh Allah memiliki martabat yang tinggi hal tersebut telah diisyaratkan dalam al-Qur'an surah al-Mujadalah ayat 11 sebagai berikut:

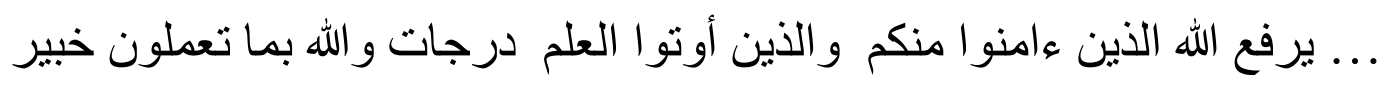

Terjemahnya :... Allah akan meninggikan orang-orang yang beriman di antara kamu dan orang-orang yang diberi ilmu pengetahuan beberapa derajat. Dan Allah maha mengetahuai apa yang kamu kerjakan.( Al-Qur'an dan Terjemahnya, 1998, h. 910-911)

Ayat tersebut menunjukkan bahwa Islam melalui al-Qur'an menempatkan Pendidikan pada segmen terpenting karena iman dan ilmu disandingkan dan menjadi prasyarat utama seorang hamba memperoleh derajat yang tinggi. Bahkan dipertegas dengan adanya perintah Allah dalam al-Qur'an tentang anjuran untuk membaca, itu berarti bahwa kebesaran dan kejayaan Islam dibangun di atas pondasi Pendidikan yang kokoh yakni pendidikan karakter. Oleh karena itu, sudah saatnya menanamkan nilai-nilai karakter yang kuat kepada anak agar terwujud generasi berkarakter.

Pendidikan karakter mutlak dibutuhkan oleh semua kalangan karena kemuliaan seseorang terletak pada karakternya. Karakter begitu penting karena dengan karakter yang baik membuat kita tahan, tabah menghadapi cobaan, dan dapat menjalani hidup dengan sempurna. Pendidikan karakter, diperlukan bukan hanya di sekolah, tapi di rumah dan di lingkungan sosial. Bahkan sekarang ini peserta pendidikan karakter bukan lagi anak usia dini hingga remaja, tetapi juga usia dewasa mutlak perlu untuk kelangsungan hidup bangsa ini. Karakter adalah kunci keberhasilan individu. Sebuah penelitian di Amerika, menemukan fakta 90 persen kasus 
pemecatan disebabkan oleh perilaku buruk seperti tidak bertanggung jawab, tidak jujur, dan hubungan interpersonal yang buruk. Selain itu, terdapat penelitian lain yang mengindikasikan bahwa 80 persen keberhasilan seseorang di masyarakat ditentukan oleh emotional quotient. ${ }^{1}$

Pembinaan pendidikan karakter dapat dilakukan melalui tripusat pendidikan yakni lingkungan keluarga (informal), lingkungan sekolah (formal) dan lingkungan masyarakat (non formal). Namun tempat paling pertama dan utama membentuk karakter anak adalah di rumah tangga dengan pendidiknya adalah kedua orang tua terutama ibu.

\section{PEMBAHASAN}

\section{A. Keutamaan Ibu dalam perspektif Islam}

Allah telah menempatkan seorang ibu dalam kemuliaan. Satu diantara sekian banyak kemuliaan seorang ibu adalah sebagai sosok paling pertama dan utama yang wajib menerima bakti dari seorang anak. al-Qadhi Iyadh menyatakan bahwa ibu memiliki keutamaan yang lebih besar dibandingkan ayah. Sebagaimana dalam sebuah hadis yang artinya:

"Dari Abu Hurairah, ia berkata: seseorang datang kepada rasulullah saw. dan berkata, wahai rasulullah kepada siapakah aku harus berbakti pertama kali? Nabi menjawab, ibumu! Orang tersebut bertanya kembali, kemudian siapa lagi? Nabi menjawab ibumu! Orang tersebut bertanya kembali, kemudian siapa lagi? Beliau menjawab, ibumu! Orang tersebut bertanya kembali kemudian siapa lagi? Nabi menjawab, kemudian kepada ayahmu." (Bukhari, 5971 dan Muslim, 2548)

Imam al-Qurthubi menjelaskan bahwa hadis tersebut menunjukkan bahwa kecintaan dan kasih sayang terhadap seorang ibu harus tiga kali lipat besarnya dibandingkan terhadap seorang ayah. Nabi saw. menyebutkan kata ibu sebanyak tiga kali, sementara kata ayah satu kali. Bila hal itu sudah kita mengerti, realitas lain bisa menguatkan pengertian tersebut. Karena kesulitan dalam menghadapi masa hamil, kesulitan ketika melahirkan, dan kesulitan pada saat menyusui dan merawat anak hanya dialami seorang ibu. Ketiga bentuk kehormatan itu hanya dimiliki seorang ibu sedangkan seorang ayah tidak memilikinya.

\footnotetext{
${ }^{1}$ Timothi Wibowo, http://www.pendidikankarakter.com/pentingnya-pendidikan-karakter-dalamdunia-pendidikan/ diakses tanggal 20 April 2012
} 
Dalam riwayat yang lain Abdullah bin Umar berkata: Ridha Allah tergantung ridha orang tua, dan murka Allah tergantung murka orang tua.

Riwayat tersebut mengandung pengertian kewajiban mencari keridhaan kedua orang tua sekaligus larangan melakukan segala sesuatu yang memancing kemurkaan mereka. Seandainya ada seorang anak yang durhaka kepada ibunya, kemudian ibunya tersebut mendo'akan kejelekan, maka do'a ibu tersebut akan dikabulkan oleh Allah. Sebaliknya jika seorang ibu ridha kepada anaknya dan do'anya mengiringi setiap langkah anaknya niscaya rahmat taufik dan pertolongan Allah akan senantiasa menyertainya.

Berpijak dari hal ini, maka ada satu hal yang sangat penting diperhatikan baik oleh orang tua maupun anak, yaitu pentingnya hubungan yang harmonis dan saling ridha antara anak dan orang tua. Sebuah perwujudan birrul walidain yang sempurna manakala kedua belah pihak saling mengisi dengan cara menjaga dan melaksanakan hak dan kewajibanya masing-nasing. Keharmonisan antara orang tua dan anak akan mengantarkan kepada kebahagiaan dunia dan akhirat dalam sebuah keluarga.

Seorang ibu hendaknya menggunakan haknya dengan baik. Tidak sembarangan mengeluarkan kata-kata yang jelek, apalagi ditujukan kepada anaknya. Hendaknya ibu lebih dapat mengontrol setiap kata yang keluar dari mulutnya untuk ditujukan kepada naknya. Banyak ibu yang dijumpai mengobral kata-kata kotor, cacian dan umpatan kepada anaknya. Disadari atau tidak, manakala ibu sering menggunakan kata-kata jelek yang ditujukan kepada anaknya, maka hal tersebut akan berpengaruh negatif bagi perkembangan psikologis anak, sehingga mempengaruhi pula pembentukan kepribadian anak. (Asadullaoh al-Faruq, 2011, h. 23). Adapun bagi seorang anak hendaknya ia berusaha sebaik mungkin berbakti kepada kedua orang tuanya terutama kepada ibunya. Anak mestinya berusaha menjaga diri sebaik-baiknya agar jangan sampai ibu mengatakan kata-kata yang buruk kepadanya.

Seorang ibu berperan sebagai pendidik pertama dan utama. Apapun pofesinya ia tetap seorang ibu yang tugas pokoknya adalah mendidik anak-anaknya. Sebagai contoh Khadijah isteri nabi adalah seorang pengusaha sukses tapi tetap dia adalah seorang ibu mendampingi suami dan mendidik anak-anaknya dengan baik. 
Bila peran utama seorang ibu dilaksanakan sebaik-baiknya, maka ibu akan dapat mengantarkan anak-anaknya ke surga. Kisah seorang yang datang menghadap kepada rasulullah saw. seraya meminta izin untuk ikut andil berjihad bersama beliau, maka beliau bertanya: adakah engkau masih mempunyai ibu? Orang itu menjawab, ya masih. Kemudian rasulullah bersabda yang artinya: "jagalah ia, karena surga itu ada di bawah telapak kakinya."

Inilah sisi luar biasa seorang ibu. Sebuah kenyataan yang mau tidak mau harus diakui oleh seorang anak untuk berbakti kepada ibunya dengan sungguh-sungguh. Jika seorang anak mengharapkan surga , maka ia dapat meraihnya dengan berbakti kapada ibunya dengan sebenarbenar bakti.

Disatu sisi, anak dituntut untuk bersungguh-sungguh berbakti kepada ibunya agar Allah memudahkannya memperoleh surga. Disisi lain, seorang ibu juga harus menciptakan jalan bagi anak-anaknya untuk mencapai surga dalam arti sebenarnya. Ibu harus memberikan pendidikan agama untuk anak-anaknya, menanamkan karakter yang baik sejak dini kepada mereka, menjadi teladan pertama dalam menjalankan segala perintah Allah dan menjauhi segala larangannya.

\section{B. Strategi Ibu Dalam Membentuk Karakter Anak dalam Lingkungan Keluarga}

Istilah strategi berasal dari bahasa Yunani, yaitu strategeia (stratus $=$ militer; dan ag $=$ memimpin), yang artinya seni atau ilmu untuk menjadi seorang jenderal. Konsep ini relevan dengan situasi pada zaman dahulu yang sering diwarnai perang, disaat seorang jenderal dibutuhkan untuk memimpin suatu angkatan perang agar dapat selalu memenangkan perang. (Tjipto Fandi, 1999, h. 3) Syaiful Bahri Djamarah memberi pengertian sebagai suatu garis besar haluan untuk bertindak dalam mencapai sasaran yang telah ditentukan. Jika strategi dihubungkan dengan belajar-mengajar, strategi bisa diartikan sebagai pola-pola umum kegiatan guru dalam mengarahkan anak didik dalam perwujudan kegiatan pembelajaran untuk mencapai tujuan yang telah digariskan. (Syaiful Bahri Djamarah, 2006, h. 52). Dengan demikian, strategi pada intinya adalah langkah-langkah terencana yang bermakna luas dan mendalam yang dihasilkan dari sebuah proses pemikiran dan perenungan yang mendalam berdasarkan pada teori dan pengalaman tertentu. (Abuddin Nata, 2009, h. 206). Namun kata strategi dalam tulusan ini dikaitkan dengan tugas ibu dalam mendidik anak dalam lingkungan keluarga. 
Islam sangat memperhatikan pendidikan manusia sejak lahir, walaupun manusia lahir dalam keadaan fitrah (suci), akan tetapi dia mempunyai dua potensi, yaitu bisa menjadi baik karena pendidikan yang benar dan bisa juga menjadi jahat tidak berpendidikan bahkan jauh dari norma-norma agama dan karakter yang baik akibat salah asuhan. (Imam Musbikin, 2003, h. 55). Untuk itulah diperlukan pendidik yang tangguh, bermental kuat menghadapi berbagai sikap anak. Pendidik pertama dan utama yang menjadi tulang punggung keberhasilan pendidikan karakter adalah ibu.

Ibu mempunyai tanggung jawab untuk membahagiakan anak-anaknya, dari sejak anaknya membuka mata hingga menutup mata. Bukan untuk memanjakannya sepanjang waktu, atau bahkan menuruti segala keinginan anak, tetapi menuntunnya untuk bisa meraih kebahagiaan di dunia dan di akhirat dengan cara mengajar anak-anaknya untuk memahami agama dengan benar, selalu bersyukur dengan segala kenikmatan yang diperoleh dan selalu bersabar atas setiap permasalahan yang dihadapi. Tak kalah pentingnya adalah menanamkan karakter kepada anakanaknya agar tumbuh menjadi manusia yang tangguh menghadapi pahit getirnya kehidupan. Untuk membentuk karakter anak ada beberapa hal yang dapat dilakukan oleh orang tua khususnya oleh ibu sebagai berikut:

1. Memberi nama yang baik pada anak

Anak seharusnya cepat tanggap terhadap kehidupan yang sedang berkembang. Oleh karenanya anak harus memiliki identitas ketika berintenraksi dan berhubungan dengan orang lain. Maka dari itu, anak-anak yang baru lahir harus diberi nama sebagus mungkin, nama-nama yang bermakna agar kelahirannya di dunia juga membawa kemandirian identitas baginya.

Banyak nama dan kata di dunia ini menjelaskan benda-benda yang ada. Nama-mana itu tentu memiliki sejarahnya, yang menjelaskan asal-usul sesuatu itu. Demikian juga dengan pemberian nama pada anak-anak kita. Begitu dia lahir bertemu dengan seseorang yang pertama ditanyakan siapa dia? Pertama-tama namalah yang ditanyakan. Karena nama begitu dekat dengan seseorang, kebanggaan seseorang ada pada namanya sekaligus merupakana suatu bentuk identifikasi diri yang sangat penting dan dalam banyak hal berpengaruh pada psikologisnya, 
yang tak jarang pula berkaitan dengan pertanyaan: siapakah diriku dilihat dari namaku? Apakah arti namaku?

Pentingnya nama ini berkaitan dengan fakta adanya interaksi antar anak yang kadang juga mengolok-olok dengan memakai nama. Tak jarang kita jumpai anak kecil yang mengolokolok nama-nama yang dianggap jelek. Kadang anak kita tidak tahu makna namanya di saat anak lain membanggakan namanya. Banyak anak malu gara-gara ia beranggapan bahwa namanya jelek, padahal yang penting bukan jelek atau tidak melainkan kalau dia tahu namanya. Jadi tugas kita sebagai orang tua adalah menggunakan "politik penamaan" ini untuk memotivasi anak kita melakukan hal-hal yang positif. Kita harus membuat anak kita bangga pada namanya dan membuat mereka tahu bahwa nama mereka berarti baik. (Fatchul Mu'in, 2011, h.375)

Sebagai contoh memberi nama anak kita dengan nama orang besar seperti Suharto dengan harapan anak tersebut dapat berpengaruh ketika ia dewasa. Orangtua terutama ibu jangan segan-segan menegur anak dengan mengaitkan dengan nama mereka bahwa namanya adalah orang besar. Misalnya pada saat anak kita malas belajar, kita dapat berkata kepada mereka, "bagaimana ini, Soekarno kok malas belajar? Bagaimana nanti bisa memimpin massa dan berpidato di hadapan orang banyak kalau mengerjakan tugas saja tidak mau'. (Fatchul Mu'in, 2011, h.376)

Kadang orangtua tidak memanfaatkan cara seperti itu, padahal secara psikologis, hal semacam itu masuk dalam perasaan mereka, baik sadar maupun tidak. Orang tua lebih suka menegur atau menyuruh anak dengan pragmatis, misalnya mengatakan: hayyo kalau tidak belajar nanti saya tidak ikutkan nonton sirkus" atau "wah gimana ibu mau belikan baju baru kalau kamu malas-malasan dan tak membantu mama. Kadang juga anak dimarahi agar menurut sehingga anak merasa terpaksa berbuat baik. Jelas hal tersebut menjukkan ketidak harmonisan hubungan antara orang tua dengan anak. Cara seperti itu merupakan sesat berpikir dalam mendidik anakanak kita.

2. Memaksimalkan perkembangan otak anak

Perkembangan otak akan mempengaruhi kecerdasan anak di kemudian hari. Hal yang mempengaruhi perkembangan otak anak hingga usia 3 tahun antara lain faktor gen, asupan 
nutrisi, kasih sayang dan stimulasi. Demikian dikatakan Dr Soedjatmiko dalam roadshow seminar "Memaksimalkan Kecerdasan Anak dengan Floor Time" di Balai Kartini, Jakarta, Sabtu (24/1). Menurut Soedjatmiko, faktor gen dari orang tua memang sudah tak bisa diubah. "Ini sudah tak bisa diganggu gugat, misal orang tua cerdas, maka faktor gen akan menurun ke anak," jelasnya. Sedangkan penambahan nutrisi terhadap bayi akan memberi efek positif bila diberikan sedini mungkin yakni sekitar 6-12 bulan. "Perkembangan otak bayi setelah dilahirkan lebih penting dalam menentukan IQ anak di kemudian hari dibanding saat di dalam kandungan," tuturnya. Nutrisi yang terbaik untuk bayi, dikatakan Soedjatmiko, Air Susu Ibu (ASI) mengandung banyak zat yang diperlukan seperti protein dan asam amino, AA-DHA, Gangliosida (GA), kolin dan zat gizi mikronutrien lainnya. Oleh karenanya seharusnya ibu memberi ASI akslusif pada bayinya minimal 6 bulan. Bahkan kalau dalam al-qur'an anjuran pemberian ASI pada anak dapat dilakukan selama 2 tahun (Q.S. al- Baqarah/2: 228).

Di samping nutrisi, stimulasi juga memegang peranan penting dalam mekasimalkan kecerdasan anak. "Stimulasi diperlukan agar hubungan antar sel syaraf otak (sinaps) dapat berkembang, karena bila tak distimulasi sinaps yang jarang atau tak terpakai akan musnah," jelasnya. Stimulasi ini dapat diterapkan sejak dini yakni sejak janin masih dalam kandungan hingga umur 2-3 tahun yang dikenal dengan masa keemasan perkembangan otak anak (golden age). Stimulasi, menurut Soedjatmiko, dapat dilakukan dengan bermain aktif dengan penuh kasih sayang, gembira dan bebas. "Faktor kasih sayang ini juga penting, karena kedekatan emosional saat orang tua dan anak itu bermain dapat menstimulasi anak untuk berpikir kreatif," jelasnya. (www.kompas.com Sabtu, 24 Januari 2009).

\section{Melatih Kemandirian dari Dalam Rumah}

Collete Dowling, seorang psikolog mengatakan, "Kebebasan dan kemandirian tak bisa diminta dari orang lain, tetapi harus dikembangkan dengan susah payah dari dalam diri. Untuk meraihnya kita harus melepaskan ketergantungan yang sebelumnya kita pergunakan sebagai tongkat untuk merasa aman, yakin pada diri sendiri tidak harus mengelabuinya dengan mimpimimpi kosong tentang berbagai hal yang terlalu jauh dari jangkauan. Ia realistis, berdiri mantap, ia merdeka untuk mencintai orang lain karena ia mencintai dirinya sendiri. (Collete Dowling, 1995, h. 50) 
Kemandirian merupakan suatu kondisi mental yang penting. Dengan kemandirian, manusia merasa bahwa dirinya bertanggung jawab terhadap dirinya dan memahami bahwa untuk mendapatkan sesuatu dibutuhkan proses. Pelan-pelan tapi pasti seorang ibu harus mengenalkan pada anak bahwa segala sesuatu harus diaraih melalui perjuangan. Hidup adalah perjuangan, maka berjuanglah untuk hidup dan menjadi pemenang jangan jadi pecundang.

Menanamkan kemandirian kepada anak hendaknya dimulai sedini mungkin, contoh kecil namun besar manfaatnya bagi tumbuhnya kemandirian pada anak adalah mengajarinya makan dengan mandiri tanpa menyuapi. Ada beberapa hal yang dapat dilakukan orangtua terutama ibu untuk merangsang anak sedini mungkin bisa makan sendiri, antara lain:

Pertama diperlukan kursi khusus supaya posisi si balita sejajar dengan permukaan meja. Dengan kebiasaan duduk sama-sama, si anak dilatih untuk dapat meniru kebiasaan makan orang dewasa yang ada dalam keluarganya.

Kedua, melatih anak makan di usia dini memerlukan banyak kesabaran dan waktu, akan tetapi seharusnya dilakukan sebab semakin cepat kita ajari untuk mandiri semakin memudahkan orangtua terutama ibu tidak tersita waktu yang banyak untuk menyuapi anak dan anakpun dapat belajar mandiri yang pada awalnya hanya makan secara mandiri tapi seiring dengan berjalannya waktu maka anak akan mandiri terhadap berbagai hal.

Ketiga, diperlukan pengorganisasian agar suasana saat makan menjadi menyenangkan bagi anak, karena anak lebih suka bermain sehingga orang tua harus mampu melibatkan anak makan bersama-sama keluarga lainnya dalam suasana yang menyenangkan.

Keempat, biasakan anak makan di dalam rumah dan hindari anak makan di halaman atau di jalan. Untuk mengajak mereka betah duduk, bermainlah sekedarnya. Untuk mengajak mereka betah duduk, bermainlah sekedarnya dengan permainan yang ringan-ringan saja. Kebiasaan ini bisa dikombinasikan dengan sang ibu sesekali menyuapi asalkan si anak mau duduk di kursi makan dengan tenang dan tetap dipancing agar anak berinisiatif untuk minta makan tanpa disuapi.

Kelima, pentingnya pengaturan keindahan makanan dan menciptakan variasi menu sehingga sajian makanan tampak menarik bagi anak-anak. Variasi makanan ini tidak tergantung 
pada mahalnya melainkan terletak pada kreativitas sang ibu dalam menata makanan di meja makan dan piring yang dipakai sebaiknya bervariasi sambil ibu mengatakan bahwa makanan yang dibuatnya sangatlah enak untuk memancing anak mudah memakannya.

Keenam, ibu harus memberi pujian ketika sang anak berhasil menghabiskan makanannya. Pujian dibutuhkan untuk menyemangati anak agar semakin suka makan sendiri. (ibid., h. 390).

\section{Berkomunikasi Secara Sehat dengan Anak}

Komunikasi memegang peranan sangat penting bagi hubungan apa saja. Demikian halnya komunikasi anatara orang tua dengan anak menjadi dasar bagi pertumbuhan mental dan psikologis yang baik bagi anak-anak.

Komunikasi yang lebih intim melibatkan kontak fisik berupa sentuhan, elusan dan dekapan akan membuat anak merasa secure dan nyaman. Orang yang dimasa kanak-kanaknya kekurangan keintiman dan sekuritas psikologis cenderung akan memiliki instabilitas kejiwaan anak, bahkan yang paling membahayakan anak akan mengalami mentalitas berupa ketidakmampuan berhubungan dengan orang lain (psikopat) sampai dewasa.

Majalah Parents edisi Agustus 1999 menuliskan sejumlah aktivitas keseharian yang amat baik bagi anak di masa mendatang jika dilakukan. Salah satu kegiatan yang harus dilakukan oleh orangtua adalah murah senyum. Semakin banyak orangtua tersenyum lebih mudah pula bagi anak tersenyum serta mendapat perasaan yang menggembirakan. (Sintha Ratnawati, 2000, h. 21). Senyum meskipun sangat sederhana, bisa melepaskan ketegangan dan segera meningkatkan kegembiraan. Kendati tidak ingin tersenyum, para ilmuan menganjurkan agar jangan segansegan memaksa bibir anda untuk tersenyum karena hal itu akan meningkatkan semangat anda. Jangan tunjukkan tindakan ngambek atau uring-uringan karena anda orangtua dan bukan anakanak. Senyum yang indah akan membuat suasana menjadi indah dan nyaman, situasi yang sangat dibutuhkan anak-anak.

5. Menjadikan Alam sebagai Sekolah bagi Anak

Alam bukan hanya gunung, melainkan juga manusia dengan berbagai persoalannya, maka manusia yang peduli pada alam akan kembali pada alam dimana manusia lain akan dibela dari kenistaan dan penindasan. Makna alam disini adalah dunia yang luas, yang terus dilaluinya 
dalam posisinya sebagai pengembara yang berkeliling untuk mengabdikan diri dalam upaya memberantas kejahatan dan membela kemanusiaan.

Oleh karena itu didiklah anak-anak kita dengan penuh kesadaran bahwa dia adalah bagian dari alam, dia bertanggung jawab bagi kehidupannya. Dengan mengetahui alam yang luas dan manusia hanyalah bagian kecil di dalamnya yang sebagian kecil di dalamnya itu melakukan penindasan terhadap yang lain, dengan demikian anak akan memiliki basis pengetahuan untuk peduli dan kelak akan membela hak-hak orang tertindas.

\section{PENUTUP}

Berdasarkan pembahasan yang telah kami paparkan terdahulu, maka dapat ditarik kesimpulan sebagai berikut:

1. Posisi ibu dalam pandangan Islam sangatlah mulia. Sebagai bukti mulianya kedudukan ibu dalam ajaranIslam, seorang ibu berhak memperoleh bakti dari seorang anak sebanyak tiga kali lipat dibanding ayah. Kemuliaan itu juga disinyalir bahwa surga terletak di telapak kaki ibu bahkan ridha Allah tergantung pada ridhahnya orangtua terutama ibu.

2. Seorang ibu sangat berperan dalam membentuk karakter anak. Untuk melakukan tugas mulia tersebut seorang ibu dapat melakukan berbagai hal seperti:
a. Memberi nama yang baik pada anak
b. Memaksimalkan perkembangan otak anak
c. Melatih Kemandirian dari Dalam Rumah
d. Berkomunikasi Secara Sehat dengan Anak
e. Menjadikan Alam sebagai Sekolah bagi Anak

\section{DAFTAR PUSTAKA}

Aunillah, Nurla Isna. Panduan Menerapkan Pendidikan Karakter di sekolah Cet. I; Jakarta: Laksana, 2011.

Djamarah, Syaiful Bahri dan Aswan Zain, Stategi Belajar Mengajar Cet I; Jakarta: Rineka Cipta, 2006.

Dowling, Collete. Tantangan Wanita Modern: Ketakutan wanita dan Kemandirian. Cet. I; Jakarta: Erlangga, 1995. 
Fandi, Tjipto. Strategi Pemasaran Cet. I; Yogyakarta: Andi, 1999.

Imam Musbikin, Kudidik Anakku dengan Bahagia. Cet. I; Jakarta: Mitra Pustaka, 2003.

Koesoema A, Doni, 2010. Pendidikan Karakter, Strategi Mendidik Anak di Zaman Global. Jakarta: PT Gramedia Widiasarana.

Mu'in, Fatchul. Pendidikan Karakter Konstruksi Teoretik dan Praktik: Urgensi Pendidikan Progresif dan Revitalisasi Peran Guru dan Orang Tua, Cet.I; Jakarta: ar-Ruzz Media, 2011.

Nata, Abuddin Perspektif Islam tentang Stategi Pembelajaran Cet.I; Jakarta: Kencana, 2009

Ratnawati, Sintha. Keluarga Kunci Sukses Anak. Cet. I; Jakarta: Kompas, 2000.

Samani, Muchlas dan Hariyanto, MS, Konsep dan Model Pendidikan Karakter Cet.II; Bandung: Remaja Rosdakarya,2011.

Zubaedi, Desain pendidikan Karakter: Konsepsi dan Aplikasinya dalam Lembaga Penididkan Cetpat ditarik .I; Jakarata: Kencana, 2011.

Zuhdi, Darmiyati. Pendidikan Karakter Cet. I; Yogyakarta: UNY Press, 2009. 